\title{
Current account sustainability in Central and Eastern Europe: Structural change and crisis
}

\author{
Juan Carlos Cuestas ${ }^{\mathrm{a}, \mathrm{b}, \mathrm{c}}$ \\ Mercedes Monfort ${ }^{\mathrm{a}}$ \\ ${ }^{a}$ Department of Economics and IEI, Jaume I University, Spain. \\ ${ }^{b}$ Department of Economics and Finance, Tallinn University of Technology, Estonia. \\ ${ }^{c}$ Research Unit, Eesti Pank, Estonia.
}

\begin{abstract}
In this paper we analyse the evolution of the current account as a percentage of GDP for a group of Central and Eastern European Countries. Instead of analysing only the variable for unit roots, we go a step further and test for different speeds of mean reversion dependent on break dates endogenously determined. We apply the Bai and Perron method to find that most countries have managed to balance their current account, but some of them should keep an eye on the low speed of mean reversion and the deviation of the time trend from balance.
\end{abstract}

Key words: debt; Central and Eastern Europe; structural breaks; European integration.

JEL code: C22, F15.

\begin{abstract}
Acknowledgements
Juan Carlos Cuestas acknowledges the financial support from the MINEIC-AEI-FEDER ECO2017-85503-R and ECO2017-83255-C3-3-P projects, both of them from 'Ministerio de Economía, Industria y Competitividad' (MINEIC), 'Agencia Estatal de Investigación' (AEI) Spain and 'Fondo Europeo de Desarrollo Regional' (FEDER).
\end{abstract}

Corresponding author. Email: cuestas@uji.es 


\section{Introduction}

Analysis of current account sustainability has been the focus not only of policy studies but also of academic studies since the Great Recession and the debt crisis that a number of European countries suffered as a consequence (Cuestas and Staehr 2013, Cuestas et al. 2014). This analysis is relevant given that basic macroeconomics predicts that an increase in the current account deficit will come at the expense of an increase in the public deficit or a reduction in private saving over investment.

The research question of this paper asks whether the current accounts of a group of transition countries from Central and Eastern Europe (CEECs) have become more or less sustainable since the Great Recession started. Related to this question, Holmes (2004) and Cuestas (2013) analysed the current account sustainability of these countries using tests for the order of integration of the variables to account for fractional integration and nonlinearities. It has become popular in the empirical analysis to use unit root tests and other tests for the order of integration of the current account because if shocks have permanent effects, like unit root processes do, the variable will not revert to the equilibrium after a shock, and so policy action will be needed to counteract the effects of the initial shock. However, if the variable is stationary, shocks only have transitory effects and the variable will revert to the equilibrium after some time. Even though the transversality condition derived from the intertemporal budget constraint will be satisfied for higher orders of integration of debt according to Bohn (2007), analysing the order of integration has been a popular way of analysing the sustainability of the current account (see Taylor 2002, Christopoulos and León-Ledesma 2010, Holmes and Panagiotidis 2009, Cunado et al. 2010 and Trehan and Walsh 1991, amongst many others).

This suggests that blithely or blindly accumulating debt may yield an inherent fragility (Grauwe 2012, Gros 2012), given that countries within the Economic and Monetary Union (EMU) cannot use monetary policy to finance deficits. 
We focus on a group of CEECs made up of Bulgaria, Czechia, Estonia, Hungary, Latvia, Lithuania, Poland, Romania, Slovakia and Slovenia, and test what the speed of mean reversion has been in the past 20 years and, more importantly, how it has changed. We particularly want to see how crises have affected this key variable. This analysis is relevant as some of these countries have already become full members of the EMU, while others still need to fulfil the Maastricht criteria.

This paper analyses how the speed of mean reversion has changed during the past 20 years. To do so we estimate equations like those of Bai and Perron (1998, 2003a, 2003b), which allows us (1) to test for a maximum number of structural breaks, (2) to obtain endogenously the dates of the breaks, and (3) to estimate equations where the coefficients are allowed to be different in the different sub-periods.

The remainder of the paper is organised as follows. In the next section we briefly summarise the issue of current account deficits in CEECs. Section 3 summarises the econometric methodology. In section 4 we present the data and the main results, and finally, section 5 concludes.

\section{Current account sustainability and CEECs: a brief}

Current account deficit is an indicator that foreign capital is needed to finance an excess of investment over private national saving, combined with an excess of public expenditure over government income. A continued deficit may yield an explosive accumulation of external debt with an increased risk of default.

Our target countries from Central and Eastern Europe have experienced a process of profound economic integration since the fall of the Soviet Union (Cuestas and Gil-Alana 2011). Although these countries have a common history, their degrees of integration with the EU are different. Slovenia has been a member of the euro area since 2007 for example, Slovakia since 2009, 
Estonia since 2010, and Latvia and Lithuania since 2015. However, Bulgaria has a peg with the euro through a currency board, whereas the remainder maintain a floating exchange rate system.

In addition, these countries have experienced an increase in the real value of their currencies in international markets, mainly due to the Balassa-Samuelson effect (Balassa 1964 and Samuelson 1964), whereby countries experience real exchange rate appreciations as they grow faster. Given that countries have to join the Exchange Rate Mechanism II (ERM II) when they become formal candidates to adopt the euro, and that imposes a semi-fixed exchange rate against the euro with $15 \%$ fluctuation bands, an appreciating real exchange rate will worsen their current account (Roubini and Wachtel 1998). This means that joining the ERM II makes competitive devaluation of the nominal exchange rate impossible. It should be remembered that transitory current account deficits may hinder economic growth, but when deficits become structural they drain resources from the economy for debt repayment and increasing interest payments. Countries like Greece have, to their misfortune, recently experienced something like this. In addition, countries that are not yet in the euro area may face speculative attacks against their currencies if international investors expect a devaluation. For the remaining countries, measures to gain competitiveness will have to be painful structural measures (Cuestas and Ordóñez 2018, and Cuestas, et al. 2019).

In a recent contribution, Harkmann and Staehr (2018) find that the determinants of the current account for these countries are dependent on the exchange rate regime. For the countries that are not in the ERM II and do not have a currency board, the current account has mainly been driven by internal determinants, while external ones do not seem to be important. For the fixers, the current account has been driven by external factors. This justifies even further the analysis of the dynamics of their current account. 


\section{The statistical methods}

As mentioned in the introduction, the idea of this paper is to analyse the dynamics and time series properties of the current account for CEECs, paying particular attention to structural breaks and the Great Recession.

For the preliminary analysis, we apply some basic unit root tests, which are the Augmented Dickey-Fuller or ADF test (Dickey and Fuller 1979), and the test of Ng and Perron (2001).

The ADF test relies on the estimation of the autoregressive parameter in the auxiliary regression

$$
\Delta q_{t}=\rho q_{t-1}+\varepsilon_{t}
$$

with the null of unit root implying that $\rho=0$, versus the alternative of stationarity where $\rho<$ 0. Note that it is usual to include lags of the dependent variable on the right hand side of equation (1). Equation (1) may also include a constant and a time trend. In addition $\mathrm{Ng}$ and Perron (2001) proposed modified versions of existing unit root tests that use a generalised least square detrending procedure to improve the power of the tests by reducing the likelihood of type II error. To achieve this Ng and Perron (2001) developed the MZa and MZt tests, which are the modified versions of the Za and Zt tests of Phillips (1987) and Phillips and Perron (1988); the MSB is a modified version of the R1 test of Bhargava (1986); and, finally, the MPT test is a modified version of the Point Optimal Test of Elliot et al. (1996).

To gain some robustness in the analysis, and given that the previous tests at best consider linear trends, we also apply the Perron and Vogelsang (1992a, 1992b) test, since it is well known that ignoring structural breaks in the data generation process when computing the tests may affect their power (Perron 1989). Perron and Vogelsang developed modifications of the ADF test to incorporate structural changes in the deterministic components, which can be temporary in the 
additive outlier model, or permanent in the innovational outlier model. The date of the break can be endogenously determined. ${ }^{1}$

However, we have to remember that the Perron and Vogelsang tests impose one break, and only one, in the deterministic components. Since we are also interested in knowing how the speed of mean reversion changes over time, we finally estimate autoregressive equations for different sub-periods, with dates and the number of breaks selected endogenously by the procedure, applying the Bai and Perron (1998, 2003a, 2003b) method. This approach allows us to estimate the following broken-type equation:

$$
\Delta q_{t}=\gamma_{1} I\left(t<T_{b}\right)+\gamma_{2} I\left(t \geq T_{b}\right)+\alpha_{1} t I\left(t<T_{b}\right)+\alpha_{2} t I\left(t \geq T_{b}\right)+\rho_{1} I\left(t<T_{b}\right) q_{t-1}+\rho_{2} I\left(t \geq T_{b}\right) q_{t-1}+\varepsilon_{t}
$$

where $\mathrm{I}($.$) is the indicator function, which takes the value 1$ if the condition in parentheses is satisfied or 0 otherwise. In equation (2) we have assumed only one structural break, defining two temporal sub-periods for the coefficients. However, there could be as many sub-periods as necessary. Bai and Perron (2003a) also propose a sequential procedure based on an $F$-type test to choose the optimal number of breaks from a maximum. This approach lets us get different estimates for the autoregressive parameter $\rho_{i}$, which gives us an indication of how the speed of mean reversion has changed over time. ${ }^{2}$

\section{Empirical analysis}

\subsection{The data}

We select as a group of CEECs Bulgaria, Czechia, Estonia, Hungary, Latvia, Lithuania, Poland, Romania, Slovakia and Slovenia. The data for the current account as a percentage of GDP for this empirical analysis come from Eurostat series bop_gdp6_q. We use quarterly observations

\footnotetext{
${ }^{1}$ See Cuestas and Gil-Alana (2016) for other detrending methods.

${ }^{2}$ In the Appendix we also show the results of estimating threshold equations. However, the results are not directly comparable with the time-break equation estimations.
} 
from 2000Q1 until 2019Q1, except for Lithuania, Poland and Slovakia, where the data begin in 2004Q1. The data have been seasonally adjusted using the additive procedure of the $X-13$ Census method.

The data are displayed in Figure 1. The first point to notice is how the current accounts of these countries worsened in the years before the start of the Great Recession and how the structural measures they took plus a drop in consumption and internal aggregate demand improved the balance after 2008. A second observation is that Bulgaria, Romania and the Baltic states appear to have suffered the more pronounced structural breaks.

Table 1 presents some summary statistics. In most cases the average is negative and is around $-3 \%$ or $-4 \%$. However, there is wide variability between countries as for example Bulgaria reached a minimum of $-29 \%$ whereas Slovenia was at $-5 \%$.

\subsection{Results}

In Table 2 we present some preliminary results from traditional unit root tests for a model with a constant and a time trend. As reported in the table, in no case can the null of a unit root be rejected at conventional levels of significance. As mentioned earlier, this may be due to the low power of the tests in the presence of structural breaks.

In Table 3 we present the results of the unit root tests with a break in both the constant and the trend. The results show more evidence against the null of a unit root. In this case, we are only unable to reject the null of a unit root for Hungary, Latvia and Romania. The dates of the breaks are mostly around 2008, which is an indication of how the Great Recession impacted the dynamics of the current account in this group of countries. As reported by Cuestas (2013), this indicates that overall there has not been a problem of sustainability. 
However, rather than assessing the sustainability of the current account, we are more interested in how the speed of mean reversion has changed over time, paying particular attention to the beginning of the Great Recession. In Table 4 we report the estimated coefficients from the Bai and Perron method of equation (2). Only for Poland do we fail to find evidence of breaks. Bulgaria shows a decrease in the speed of mean reversion after 2008, with an increase in the trend, which implies that the deficit was reducing fast. In Czechia we find the opposite, as the speed of mean reversion increases and the trend decreases. In Estonia, we find a model with two breaks, with the second one in 2009 , after which the speed of reversion increases, which is good news as the trend also decreases. In Hungary we find two breaks, one related to the Great Recession in 2008 and another one later in 2016. In general the autoregressive parameter is quite close to -1 , indicating that mean reversion occurs at high speed, and there is a negative trend in the last sub-period estimated. In Latvia, where the tests suggest two breaks too, we find that the speed of mean reversion is relatively high in the last sub-period and the trend has dropped to a value of nearly 0. For Lithuania we find similar results, with an even higher speed of mean reversion and the second break occurring in 2014. In Poland there are again no breaks. In Romania we find similar results to those from Hungary, as the first break occurs at the beginning of the Great Recession and a second break occurs in 2015, after which the speed of mean reversion is high with a negative trend. Similar results are found for Slovakia, with only one break in 2015. Finally, for Slovenia, after the second break in 2012 we find a relatively high speed of mean reversion but accompanied by a positive trend, leading towards a greater current account surplus. In addition, it seems from looking at how the exchange rate regime affects the speed of mean reversion that the speed of mean reversion is slower for Bulgaria, Czechia, Estonia, Latvia and Lithuania as peggers, than it is for the floaters, which are Hungary, Poland, Romania, Slovakia and Slovenia. This highlights how the exchange rate can be an additional tool for helping the current account adjust to equilibrium. 
In general countries have managed to become more balanced towards the end of the period, but the positive and negative trends may imply permanent deviation for a balanced current account.

\section{Conclusion}

Stories spreading fears about countries defaulting have filled the news and most of the academic literature in the years since the Great Recession. This is no surprise after the series of debt crises that were experienced by some European countries.

In this paper we extended the literature analysing the dynamics of the current account and its sustainability. We focus on a group of CEECs that have in recent decades moved from communism to market economies and have managed to achieve a high degree of economic integration with the rest of the EU.

In particular, we observe that most of the countries have managed to balance their current accounts, but some of them need to keep an eye on those current accounts as the speed of mean reversion has fallen and the trend indicates that a permanent deviation from 0 is possible.

As avenues for future research we propose that the current account determinants could be analysed incorporating breaks, or how the equilibrium relationship may have changed over time, in particular after the beginning of the Great Recession and recovery. Digging deeper into the causes of the breaks, we also propose the threshold relations could be analysed to obtain the key variables that condition the relationship between the current determinants and their fundamentals. 
Figure 1: Current account as a percentage of GDP, seasonally adjusted
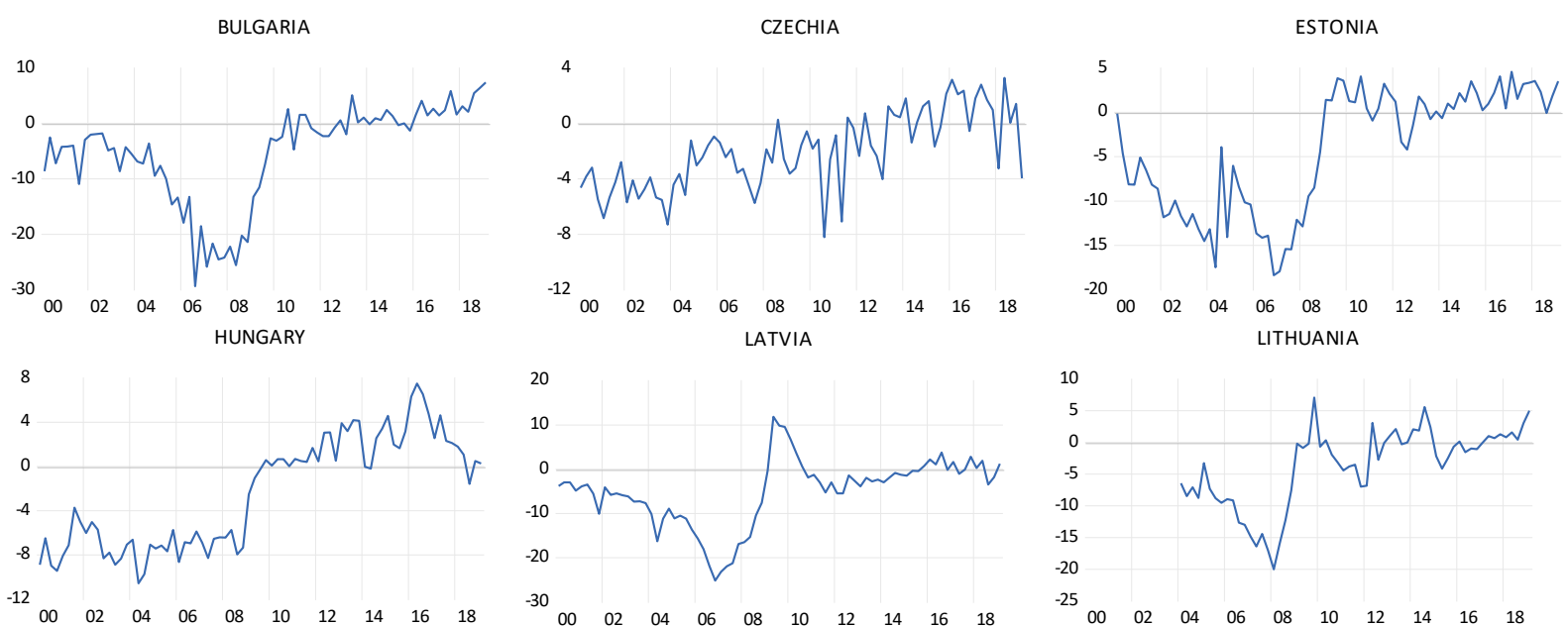

POLAND

ROMANIA
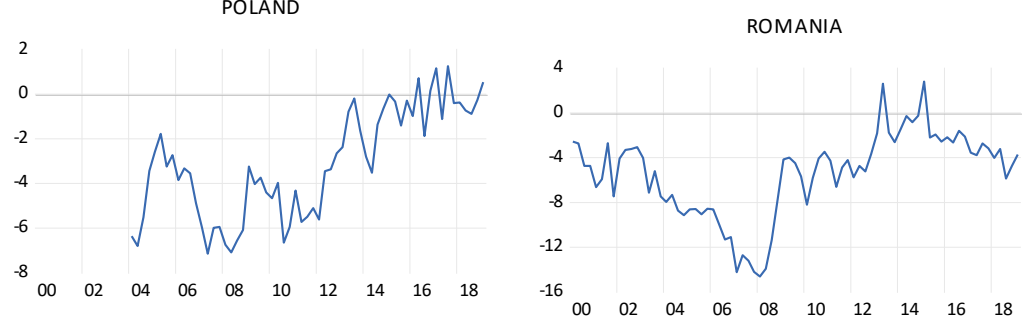
SLOVAKIA

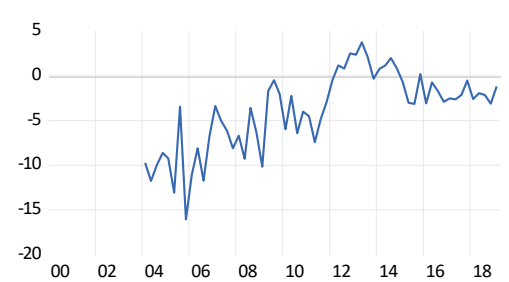
SLOVENIA

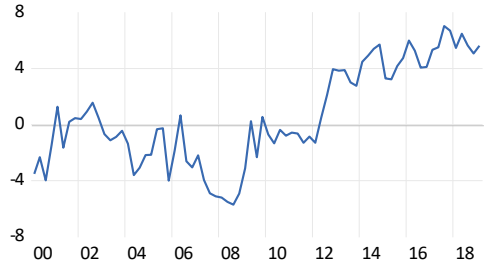


Table 1: Summary statistics of the seasonally adjusted data

\begin{tabular}{|c|c|c|c|c|c|c|c|c|c|c|}
\hline & BULGARIA & CZECHIA & ESTONIA & HUNGARY & LATVIA & LITHUANIA & POLAND & ROMANIA & SLOVAKIA & SLOVENIA \\
\hline Mean & -5.312846 & -2.042746 & -4.269305 & -2.343341 & -5.087153 & -3.776682 & -3.115413 & -5.437568 & -3.900793 & 0.568171 \\
\hline Median & -2.513431 & -2.339180 & -0.948616 & -1.049816 & -3.424413 & -1.900292 & -3.318217 & -4.491944 & -2.993021 & -0.264649 \\
\hline Maximum & 7.408029 & 3.281169 & 4.578741 & 7.482895 & 11.80658 & 7.070815 & 1.253160 & 2.813671 & 3.760244 & 7.035793 \\
\hline Minimum & -29.38239 & -8.212143 & -18.36721 & -10.55393 & -25.16897 & -19.99968 & -7.144377 & -14.61401 & -16.05177 & -5.731484 \\
\hline Std. Dev. & 8.736786 & 2.735097 & 6.876539 & 4.980845 & 7.576023 & 6.177442 & 2.417104 & 3.775658 & 4.357872 & 3.534674 \\
\hline Skewness & -1.058308 & 0.019503 & -0.455406 & 0.078149 & -0.625572 & -0.749474 & 0.007686 & -0.622888 & -0.594897 & 0.142851 \\
\hline Kurtosis & 3.286720 & 2.246582 & 1.761095 & 1.595221 & 3.410714 & 2.809757 & 1.810703 & 3.159107 & 2.793711 & 1.907818 \\
\hline Jarque-Bera & 14.63730 & 1.826056 & 7.585990 & 6.409711 & 5.563395 & 5.802725 & 3.595602 & 5.060414 & 3.706163 & 4.088983 \\
\hline Probability & 0.000663 & 0.401307 & 0.022528 & 0.040565 & 0.061933 & 0.054948 & 0.165663 & 0.079643 & 0.156753 & 0.129446 \\
\hline Sum & -409.0891 & -157.2914 & -328.7365 & -180.4373 & -391.7108 & -230.3776 & -190.0402 & -418.6927 & -237.9483 & 43.74917 \\
\hline Sum Sq. Dev. & 5801.189 & 568.5375 & 3593.796 & 1885.470 & 4362.106 & 2289.647 & 350.5436 & 1083.425 & 1139.463 & 949.5379 \\
\hline Observations & 77 & 77 & 77 & 77 & 77 & 61 & 61 & 77 & 61 & 77 \\
\hline
\end{tabular}

Table 2: Unit root tests results: model with a constant and a trend.

\begin{tabular}{|c|c|c|c|c|c|}
\hline & ADF & $\mathrm{MZa}$ & $\mathrm{MZt}$ & MSB & MPT \\
\hline Bulgaria & -1.369914 & -2.67273 & -1.10771 & 0.41445 & 32.4757 \\
\hline Czechia & -1.745121 & -4.18191 & -1.16978 & 0.27972 & 19.2060 \\
\hline Estonia & -2.665427 & 21.3312 & 21.3312 & 21.3312 & 21.3312 \\
\hline Hungary & -1.164161 & -5.84918 & -1.58418 & 0.27084 & 15.3993 \\
\hline Latvia & -2.035239 & -6.04655 & -1.73268 & 0.28656 & 15.0653 \\
\hline Lithuania & -2.833669 & -11.5814 & -2.39403 & 0.20671 & 7.93373 \\
\hline Poland & -2.455238 & -11.2938 & -2.37186 & 0.21001 & 8.09182 \\
\hline Romania & -2.673304 & -8.31734 & -2.03786 & 0.24501 & 10.9607 \\
\hline Slovakia & -0.751450 & -6.81930 & -1.81540 & 0.26622 & 13.3929 \\
\hline Slovenia & -1.664205 & -5.89376 & -1.71158 & 0.29041 & 15.4545 \\
\hline \multicolumn{6}{|l|}{ Critical values } \\
\hline $1 \%$ & -4.085092 & -23.8000 & -3.42000 & 0.14300 & 4.03000 \\
\hline $5 \%$ & -3.470851 & -17.3000 & -2.91000 & 0.16800 & 5.48000 \\
\hline $10 \%$ & -3.162458 & -14.2000 & -2.62000 & 0.18500 & 6.67000 \\
\hline
\end{tabular}

Note: Lag length chosen using the Modified Bayesian Information criteria proposed by Ng and Perron (2001). The M-tests are the modified tests proposed by $\mathrm{Ng}$ and Perron (2001). 
Table 3: Unit root tests results with breaks: model with a constant and a trend

\begin{tabular}{|c|c|c|}
\hline & ADF Innov. & ADF Addit. \\
\hline Bulgaria & $\begin{array}{c}-4.706629 \\
2008 Q 4\end{array}$ & $\begin{array}{c}-3.636333 \\
208 Q 2\end{array}$ \\
\hline Czechia & $\begin{array}{c}-7.581664 * * * \\
2006 \mathrm{Q} 3\end{array}$ & $\begin{array}{c}-8.084753 * * * \\
2013 Q 4\end{array}$ \\
\hline Estonia & $\begin{array}{c}-4.873168 \\
2008 \mathrm{Q} 3 \\
\end{array}$ & $\begin{array}{c}-5.015014 * \\
2008 \mathrm{Q} 2 \\
\end{array}$ \\
\hline Hungary & $\begin{array}{c}-3.038966 \\
2002 Q 2 \\
\end{array}$ & $\begin{array}{c}-4.611413 \\
2008 \mathrm{Q} 3 \\
\end{array}$ \\
\hline Latvia & $\begin{array}{c}-4.342604 \\
2008 \mathrm{Q} 2 \\
\end{array}$ & $\begin{array}{c}-4.390090 \\
2008 \mathrm{Q} 2 \\
\end{array}$ \\
\hline Lithuania & $\begin{array}{c}-5.072474 * \\
2008 \mathrm{Q} 3\end{array}$ & $\begin{array}{c}-5.179158^{* *} \\
2008 \mathrm{Q} 2\end{array}$ \\
\hline Poland & $\begin{array}{c}-4.722972 \\
2006 \mathrm{Q} 3\end{array}$ & $\begin{array}{c}-4.908344^{*} \\
2006 \mathrm{Q} 3\end{array}$ \\
\hline Romania & $\begin{array}{c}-3.272234 \\
2003 \mathrm{Q} 1\end{array}$ & $\begin{array}{c}-4.019008 \\
2009 \mathrm{Q} 1\end{array}$ \\
\hline Slovakia & $\begin{array}{c}-7.768305 * * * \\
2012 \mathrm{Q} 1 \\
\end{array}$ & $\begin{array}{c}-8.036491 * * * * \\
2012 \mathrm{Q} 1 \\
\end{array}$ \\
\hline Slovenia & $\begin{array}{c}-5.083752 * \\
2006 \mathrm{Q} 2\end{array}$ & $\begin{array}{c}-4.800567 \\
2007 \mathrm{Q} 1\end{array}$ \\
\hline \multicolumn{3}{|l|}{ Critical values } \\
\hline $1 \%$ & -5.719131 & -5.719131 \\
\hline $5 \%$ & -5.175710 & -5.175710 \\
\hline $10 \%$ & -4.893950 & -4.893950 \\
\hline
\end{tabular}

Note: Lag length chosen using the Modified Bayesian Information criteria proposed by $\mathrm{Ng}$ and Perron (2001). 
Table 4: Estimation of the broken equations

\begin{tabular}{|c|c|c|c|c|c|}
\hline & $\begin{array}{l}\gamma_{1} \\
\alpha_{1} \\
\rho_{1}\end{array}$ & $T_{1}$ & $\begin{array}{l}\gamma_{2} \\
\alpha_{2} \\
\rho_{2}\end{array}$ & $T_{2}$ & $\begin{array}{l}\gamma_{3} \\
\alpha_{3} \\
\rho_{3}\end{array}$ \\
\hline Bulgaria & $\begin{array}{c}4.204850 \\
{[0.09]} \\
-0.580224 \\
{[0.00]} \\
-0.608666 \\
{[0.00]}\end{array}$ & 2008Q4 & $\begin{array}{c}-6.529679 \\
{[0.11]} \\
0.118963 \\
{[0.07]} \\
-0.425749 \\
{[0.00]}\end{array}$ & - & \\
\hline Czechia & $\begin{array}{c}-5.992850 \\
{[0.01]} \\
0.091309 \\
{[0.01]} \\
-1.079728 \\
0.00]\end{array}$ & 2015Q4 & $\begin{array}{c}25.07229 \\
{[0.00]} \\
-0.333358 \\
{[0.01]} \\
-1.842564 \\
{[0.00]}\end{array}$ & - & \\
\hline Estonia & $\begin{array}{c}-17.73426 \\
{[0.00]} \\
-0.013997 \\
{[0.94]} \\
-1.553513 \\
{[0.00]}\end{array}$ & 2005Q2 & $\begin{array}{c}-11.71955 \\
{[0.00]} \\
0.304527 \\
{[0.04]} \\
-0.274373 \\
{[0.23]}\end{array}$ & 2009Q1 & $\begin{array}{c}-3.497082 \\
{[0.14]} \\
0.078085 \\
{[0.06]} \\
-0.929490 \\
{[0.00]}\end{array}$ \\
\hline Hungary & $\begin{array}{c}-7.839367 \\
{[0.00]} \\
0.027001 \\
{[0.41]} \\
-0.993067 \\
{[0.00]}\end{array}$ & 2008Q4 & $\begin{array}{c}-6.523761 \\
{[0.10]} \\
0.150901 \\
{[0.05]} \\
-0.829943 \\
{[0.00]}\end{array}$ & 2016Q1 & $\begin{array}{c}45.55984 \\
{[0.00]} \\
-0.600802 \\
{[0.00]} \\
-1.150348 \\
{[0.00]}\end{array}$ \\
\hline Latvia & $\begin{array}{c}-0.088327 \\
{[0.96]} \\
-0.525091 \\
{[0.01]} \\
-0.969585 \\
{[0.00]}\end{array}$ & 2006Q2 & $\begin{array}{c}-21.91688 \\
{[0.01]} \\
0.701886 \\
{[0.00]} \\
-0.139784 \\
{[0.42]}\end{array}$ & 2009Q3 & $\begin{array}{c}-3.943090 \\
{[0.05]} \\
0.057595 \\
{[0.08]} \\
-0.615682 \\
{[0.00]}\end{array}$ \\
\hline Lithuania & $\begin{array}{c}-9.026817 \\
{[0.21]} \\
0.043587 \\
{[0.89]} \\
-0.788665 \\
{[0.04]}\end{array}$ & 2009Q1 & $\begin{array}{c}-29.71730 \\
{[0.00]} \\
0.521016 \\
{[0.00]} \\
-2.091666 \\
{[0.00]}\end{array}$ & 2014Q2 & $\begin{array}{c}-1.834726 \\
{[0.75]} \\
0.032416 \\
{[0.71]} \\
-1.023357 \\
{[0.00]}\end{array}$ \\
\hline Poland & & & $\begin{array}{l}\text { NO BREAK } \\
\text { MODEL }\end{array}$ & & \\
\hline Romania & $\begin{array}{c}0.490866 \\
{[0.55]} \\
-0.598938 \\
{[0.00]} \\
-1.448537 \\
{[0.00]}\end{array}$ & 2008Q3 & $\begin{array}{c}-24.97600 \\
{[0.00]} \\
0.411425 \\
{[0.00]} \\
-1.165970 \\
{[0.00]}\end{array}$ & 2015Q2 & $\begin{array}{c}19.77122 \\
{[0.01]} \\
-0.353884 \\
{[0.00]} \\
-1.696295 \\
{[0.00]}\end{array}$ \\
\hline Slovakia & $\begin{array}{c}-27.98850 \\
{[0.00]} \\
0.510726 \\
{[0.00]} \\
-1.578777 \\
{[0.00]}\end{array}$ & 2015Q2 & $\begin{array}{c}10.58575 \\
{[0.30]} \\
-0.209032 \\
{[0.17]} \\
-2.198451 \\
{[0.00]}\end{array}$ & - & \\
\hline Slovenia & $\begin{array}{c}1.584527 \\
{[0.03]} \\
-0.166415 \\
{[0.00]} \\
-1.058189 \\
{[0.00]}\end{array}$ & 2009Q2 & $\begin{array}{c}-8.557118 \\
{[0.09]} \\
0.137439 \\
{[0.21]} \\
-2.252860 \\
{[0.00]}\end{array}$ & 2012Q2 & $\begin{array}{c}-5.115755 \\
{[0.04]} \\
0.135429 \\
{[0.00]} \\
-0.837921 \\
{[0.00]}\end{array}$ \\
\hline
\end{tabular}

Note: $T_{\mathrm{i}}$ indicates the date of the breaks. The regression contains 8 lags of the dependent variables, which do not change over time. P-values are given in brackets. 


\section{Appendix}

As requested by an anonymous referee we provide estimates of the threshold equations, using as potential threshold variables gross domestic product (y), its first difference, and one lag, and the real effective exchange rate (rer) based on consumer price indexes against the 27 main trade partners, with its first differences and one lag. The estimated equation is similar to equation (2), but in this case, $t$ is replaced by the threshold variable $T h$. The model choses the best threshold variable by using information criteria. The data for these two variables are also obtained from Eurostat. The results, displayed in Table A, show that depending on the case, the threshold may depend on either of those variables. However, these results are not directly comparable with those of Table 4 .

In general, though with a few exceptions, we find that the larger the $y / r e r$ or the change in them, the faster the mean reversion of the current account is to equilibrium. 
Table A: Estimation of the threshold equations

\begin{tabular}{|c|c|c|c|c|c|}
\hline & $\begin{array}{l}\gamma_{1} \\
\alpha_{1} \\
\rho_{1}\end{array}$ & $T h_{1}$ & $\begin{array}{l}\gamma_{2} \\
\alpha_{2} \\
\rho_{2}\end{array}$ & $T_{2}$ & $\begin{array}{l}\gamma_{3} \\
\alpha_{3} \\
\rho_{3}\end{array}$ \\
\hline Bulgaria & \multicolumn{5}{|c|}{ NO THRESHOLD } \\
\hline Czechia & $\begin{array}{c}-4.1315205 \\
{[0.05]} \\
0.079730 \\
{[0.03]} \\
-0.745771 \\
{[0.03]}\end{array}$ & rer $<101.2$ & $\begin{array}{c}-9.994654 \\
{[0.00]} \\
0.121604 \\
{[0.03]} \\
-1.639876 \\
{[0.00]}\end{array}$ & & \\
\hline Estonia & $\begin{array}{c}-17.24938 \\
{[0.00]} \\
0.019558 \\
{[0.92]} \\
-1.471387 \\
{[0.00]}\end{array}$ & rer $<87.36$ & $\begin{array}{c}-8.919028 \\
{[0.04]} \\
0.172783 \\
{[0.08]} \\
-0.329559 \\
{[0.03]}\end{array}$ & $87.36<$ rer $<101.76$ & $\begin{array}{c}-2.465813 \\
{[0.36]} \\
0.058994 \\
{[0.22]} \\
-0.754432 \\
{[0.00]}\end{array}$ \\
\hline Hungary & $\begin{array}{c}-7.998689 \\
{[0.00]} \\
0.186799 \\
{[0.00]} \\
-0.683546 \\
{[0.00]}\end{array}$ & $y<23287$ & $\begin{array}{c}-12.33809 \\
{[0.00]} \\
0.243086 \\
{[0.00]} \\
-0.717127 \\
{[0.00]}\end{array}$ & $23287<y<25609$ & $\begin{array}{c}48.25809 \\
{[0.09]} \\
-0.636264 \\
{[0.10]} \\
-1.304088 \\
{[0.01]}\end{array}$ \\
\hline Latvia & $\begin{array}{c}-3.225382 \\
{[0.00]} \\
0.050164 \\
{[0.01]} \\
-0.130091 \\
{[0.09]}\end{array}$ & $D(\operatorname{rer}(-1))<1.31$ & $\begin{array}{c}21.53139 \\
{[0.00]} \\
-0.373279 \\
{[0.01]} \\
0.424991 \\
{[0.00]}\end{array}$ & & \\
\hline Lithuania & $\begin{array}{c}-10.42576 \\
{[0.02]} \\
0.121005 \\
{[0.14]} \\
-0.535580 \\
{[0.00]}\end{array}$ & rer $<99.5$ & $\begin{array}{c}-7.202171 \\
{[0.02]} \\
0.120913 \\
{[0.02]} \\
-0.911049 \\
{[0.00]}\end{array}$ & & \\
\hline Poland & $\begin{array}{c}-3.340805 \\
{[0.10]} \\
0.047383 \\
{[0.09]} \\
-0.525130 \\
{[0.01]}\end{array}$ & rer $<97.2$ & $\begin{array}{c}-4.769924 \\
{[0.02]} \\
0.050046 \\
{[0.13]} \\
-0.511146 \\
{[0.03]}\end{array}$ & & \\
\hline Romania & $\begin{array}{c}-3.441805 \\
{[0.00]} \\
0.026709 \\
{[0.03]} \\
-0.451458 \\
{[0.00]}\end{array}$ & $r e r<101.24$ & $\begin{array}{c}-11.20610 \\
{[0.00]} \\
0.206183 \\
{[0.00]} \\
-0.413033 \\
{[0.00]}\end{array}$ & & \\
\hline Slovakia & $\begin{array}{c}-7.735130 \\
{[0.04]} \\
0.083044 \\
{[0.15]} \\
-0.764809 \\
{[0.00]}\end{array}$ & $\operatorname{rer}(-1)<101.26$ & $\begin{array}{c}2.437201 \\
{[0.31]} \\
-0.037204 \\
{[0.33]} \\
-0.422728 \\
{[0.03]}\end{array}$ & & \\
\hline Slovenia & $\begin{array}{c}1.425731 \\
{[0.07]} \\
-0.163930 \\
{[0.00]} \\
-1.288420 \\
{[0.00]}\end{array}$ & $\operatorname{rer}(-1)<97.62$ & $\begin{array}{c}-6.863778 \\
{[0.00]} \\
0.144654 \\
{[0.00]} \\
-0.606034 \\
{[0.00]}\end{array}$ & $97.62<\operatorname{rer}(-1)<100.60$ & $\begin{array}{c}-29.66368 \\
{[0.00]} \\
0.676375 \\
{[0.00]} \\
-2.271843 \\
{[0.00]}\end{array}$ \\
\hline
\end{tabular}

Note: $T h_{\mathrm{i}}$ indicates the threshold variable and values. The regression contains 8 lags of the dependent variables, which do not change over time. P-values are given in brackets. 


\section{References}

Bai, Jushan, and Pierre Perron. 1998. 'Estimating and Testing Linear Models with Multiple Structural Changes'. Econometrica 66(1): 47.

- 2003a. 'Computation and Analysis of Multiple Structural Change Models'. Journal of Applied Econometrics 18(1): 1-22.

_. 2003b. 'Critical Values for Multiple Structural Change Tests'. The Econometrics Journal 6(1): 72-78.

Balassa, Bela. 1964. 'The Purchasing-Power Parity Doctrine: A Reappraisal'. Journal of Political Economy 72(6): 584-96.

Bhargava, Alok. 1986. 'On the Theory of Testing for Unit Roots in Observed Time Series'. The Review of Economic Studies 53(3): 369-84.

Bohn, Henning. 2007. 'Are Stationarity and Cointegration Restrictions Really Necessary for the Intertemporal Budget Constraint?' Journal of Monetary Economics 54(7): 183747.

Christopoulos, Dimitris, and Miguel A. León-Ledesma. 2010. 'Current Account Sustainability in the US: What Did We Really Know about It?' Journal of International Money and Finance 29(3): 442-59.

Cuestas, Juan C, and Luis A Gil-Alana. 2011. Unemployment Hysteresis, Structural Changes, Non-Linearities and Fractional Integration in European Transition Economies. University of Sheffield. Sheffield Economics Research Papers 2011005.

Cuestas, Juan Carlos. 2013. 'The Current Account Sustainability of European Transition Economies'. JCMS: Journal of Common Market Studies 51(2): 232-45.

Cuestas, Juan Carlos, Luis A. Gil-Alana, and Karsten Staehr. 2014. 'Government Debt Dynamics and the Global Financial Crisis: Has Anything Changed in the EA12?' Economics Letters 124(1): 64-66.

Cuestas, Juan Carlos, and Luis Alberiko Gil-Alana. 2016. 'Testing for Long Memory in the Presence of Non-Linear Deterministic Trends with Chebyshev Polynomials'. Studies in Nonlinear Dynamics \& Econometrics 20(1).

https://www.degruyter.com/view/j/snde.2016.20.issue-1/snde-2014-0005/snde-20140005.xml (November 14, 2019).

Cuestas, Juan Carlos, and Javier Ordóñez. 2018. 'Fiscal Consolidation in Europe: Has It Worked?’ Applied Economics Letters 25(16): 1179-82.

Cuestas, Juan Carlos, Javier Ordóñez, and Karsten Staehr. 2019. 'Unit Labour Costs and the Dynamics of Output and Unemployment in the Southern European Crisis Countries'. Empirica 46(3): 597-616.

Cuestas, Juan Carlos, and Karsten Staehr. 2013. 'Fiscal Shocks and Budget Balance Persistence in the EU Countries from Central and Eastern Europe'. Applied Economics 45(22): 3211-19. 
Cunado, Juncal, Luis A. Gil-Alana, and Fernando Pérez de Gracia. 2010. 'European Current Account Sustainability: New Evidence Based On Unit Roots and Fractional Integration'. Eastern Economic Journal 36(2): 177-87.

Dickey, David A., and Wayne A. Fuller. 1979. 'Distribution of the Estimators for Autoregressive Time Series with a Unit Root'. Journal of the American Statistical Association 74(366a): 427-31.

Elliott, Graham, Thomas J. Rothenberg, and James H. Stock. 1996. 'Efficient Tests for an Autoregressive Unit Root'. Econometrica 64(4): 813-36.

Grauwe, Paul De. 2012. 'The Governance of a Fragile Eurozone'. Australian Economic Review 45(3): 255-68.

Gros, Daniel. 2012. 'On the Stability of Public Debt in a Monetary Union*'. JCMS: Journal of Common Market Studies 50(s2): 36-48.

Harkmann, Kersti, and Karsten Staehr. 2018. Current Account Dynamics and Exchange Rate Regimes in Central and Eastern Europe. Eesti Pank. Working Paper Series. https://www.eestipank.ee/sites/eestipank.ee/files/publication/en/WorkingPapers/2018/ wp08_2018.pdf (July 31, 2019).

Holmes, Mark J. 2004. 'Current Account Deficits in the Transition Economies'. Prague Economic Papers 13(4): 347-58.

Holmes, Mark J., and Theodore Panagiotidis. 2009. 'Cointegration and Asymmetric Adjustment: Some New Evidence Concerning the Behavior of the U.S. Current Account'. The B.E. Journal of Macroeconomics 9(1). https://www.degruyter.com/dg/viewarticle/j\$002fbejm.2009.9.1\$002fbejm.2009.9.1.1 665\$002fbejm.2009.9.1.1665.xml (July 30, 2019).

Ng, Serena, and Pierre Perron. 2001. 'LAG Length Selection and the Construction of Unit Root Tests with Good Size and Power'. Econometrica 69(6): 1519-54.

Perron, Pierre. 1989. 'The Great Crash, the Oil Price Shock, and the Unit Root Hypothesis'. Econometrica 57(6): 1361-1401.

Perron, Pierre, and Timothy J. Vogelsang. 1992a. 'Nonstationarity and Level Shifts with an Application to Purchasing Power Parity'. Journal of Business \& Economic Statistics 10(3): 301-20.

1992b. 'Testing for a Unit Root in a Time Series with a Changing Mean: Corrections and Extensions'. Journal of Business \& Economic Statistics 10(4): 467-70.

Phillips, P. C. B. 1987. 'Time Series Regression with a Unit Root'. Econometrica 55(2): 277301.

Phillips, Peter C. B., and Pierre Perron. 1988. 'Testing for a Unit Root in Time Series Regression'. Biometrika 75(2): 335-46. 
Roubini, Nouriel, and Paul Wachtel. 1998. Current Account Sustainability in Transition Economies. National Bureau of Economic Research. Working Paper. http://www.nber.org/papers/w6468 (July 31, 2019).

Samuelson, Paul A. 1964. 'Theoretical Notes on Trade Problems'. The Review of Economics and Statistics 46(2): 145-54.

Taylor, Alan M. 2002. 'A Century of Current Account Dynamics'. Journal of International Money and Finance 21(6): 725-48.

Trehan, Bharat, and Carl E. Walsh. 1991. 'Testing Intertemporal Budget Constraints: Theory and Applications to U. S. Federal Budget and Current Account Deficits'. Journal of Money, Credit and Banking 23(2): 206-23. 